\title{
ResearchOnline@JCU
}

This is the author-created version of the following work:

Conrad, Lettie Y., Bruce, Christine S., and Tucker, Virginia M. (2020) Constructing information experience: a grounded theory portrait of academic information management. Aslib Journal of Information Management, 72 (4) pp. 653-670.

Access to this file is available from:

https://researchonline.jcu.edu.au/63802/

Copyright (C) 2020, Emerald Publishing Limited. The Author Accepted Manuscript is deposited under Creative Commons licence CC BY-NC 4.0. Reuse is allowed in accordance with the terms outlined by the licence.

Please refer to the original source for the final version of this work: 


\section{Constructing information experience: A grounded theory portrait of academic information management}

\section{Structured abstract}

- Purpose: This paper discusses what it means to consider the information experience of academic information management from a constructivist grounded theory perspective. Using a doctoral study-in-progress as case illustration, the authors demonstrate how information experience research applies a wide lens to achieve a holistic view of information management phenomena. By unifying a range of elements, and understanding information and its management to be inseparable from the totality of human experience, an information experience perspective offers a fresh approach to answering today's research questions.

- Methodology: The case illustration is a constructivist grounded theory study, using interactive interviews, an original form of semi-structured qualitative interviews combined with card-sorting exercises (Conrad \& Tucker, 2019), to deepen reflections by participants and externalize their information experiences. The constructivist variant of grounded theory offers an inductive, exploratory approach to address the highly contextualized information experiences of student-researchers in managing academic information.

- Findings: Preliminary results are reported in the form of three interpretative categories that outline key aspects of the information experience for student-researchers. By presenting these initial results, we demonstrate how the constructivist grounded theory methodology can illuminate multiple truths and bring a focus on interpretive practices to the understanding of information management experiences.

- Implications/limitations: This new approach offers holistic insights into academic information management phenomena as contextual, fluid, and informed by meaningmaking and adaptive practices. Limitations include the small sample size customary to qualitative research, situated within one situated perspective on the academic information management experience.

- Originality/value: We demonstrate theoretical and methodological contributions of constructivist information experience research to illuminate information management in an academic setting.

\section{Introduction}

This paper discusses the unique contributions generated with constructivist grounded theory research into information experience. Using a doctoral study as case illustration, we demonstrate how adopting the construct of information experience as the focus of research can offer new insights into information management phenomena - in particular, academic information management. We begin with a brief summary of research into personal information management, 
specifically that which occurs in an academic setting, and demonstrate how this field has historically focused on information activities, interactions with information systems, and other overtly observable and explicitly defined behaviors. An overview of the emerging domain of information experience is then presented, explaining the use of information experience as a sensitizing concept in the constructivist grounded theory study illustrated here.

The doctoral work in progress poses the research question: what is the student-researcher information experience of academic information management? Using constructivist grounded theory (Charmaz, 2014), this study is investigating student-researchers who are master's-level social science scholars, conducting what is often their first exercise in academic research. The goal of this study is to illuminate the holistic, contextualized, and multiple realities which inform individual academic information management of participating master's-level students. Preliminary results are offered to demonstrate the unique value and insights available when information experience is used as a focal point of the research question. The concluding discussion outlines how this approach allows the featured study to adopt an expansive view of subjective interactions with information and to achieve a more unified understanding of student-researcher information management.

\section{Research domains and theories}

This study in progress is situated within the emerging research domain of information experience research, and it aims to offer new insights into personal information management theories. A brief summary of both personal information management, particularly in academic contexts, and information experience research are presented in this section.

Personal information management has been defined as the diverse information behaviors and needs related to the individual practice of managing information, however subjectively defined, that pertains to a single person (Jones \& Teevan, 2011). As noted in this section, both research literature and literacy standards indicate how personal information management has been tied to successful learning experiences and researcher productivity. Efforts to better understand connections between personal information management and learning or research objectives have historically focused on information use, storage, and other transactional elements - whereas this study aims to capture a holistic understanding of the information experience of academic information management. Our focus on information experience reflects paradigms shifting in information research (Tang et al., 2019), zooming out from the study of discrete information 


\section{Academic information management}

Within the fields of individual or personal information management research, studies investigate practices whereby we are "extending our control, or at least our influence" (Jones, 2012, p. 10), over the vast expanse of the world's information. This section briefly summarizes the landscape of literature addressing information management from an individual perspective and within academic settings, including studies of personal information management (PIM), information literacy (IL), and personal knowledge management (PKM). Historically, these domains have largely not adopted an experiential approach, instead favoring behavioral and skills-based models; however, we can see a progression in the field to embrace research that approaches information phenomena with a more holistic view.

Theoretical models for PIM and PIM systems have been successfully applied to examination of student information practices. For example, librarians at the University of Ghana applied the Jones / Teevan PIM model to examine their students' PIM behaviors and potential implications for library services and IL instruction (Osae Otopah \& Dadzie, 2013). Others have looked at PIM practices of teachers (Diekema \& Olsen, 2014), with an emphasis placed on overtly measurable behavior, such as meeting pre-defined learning objectives.

In many PIM studies, transactional aspects of academic information management are the primary focus, such as the research by Al-Omar \& Cox (2013), which examined information seeking, retrieval, use, and organization - all activity-based phenomena. Within library and information studies, the concept of PIM first appears within the context of IL and information behavior specifically, research information management (Genoni \& Partridge, 2000). Here, research literacy gaps were cited after examining the information behavior and research methodologies used by $\mathrm{PhD}$ 
students as well as the "skills, expectations, and experiences" of their doctoral supervisors (Genoni \& Partridge, 2000, p. 225). Those studies that look to cultural, affective, or other factors that contribute to an experiential perspective do so with a focus on observable, measurable interactions with information, such as the task-based orientation of Mizrachi and Bates' research into undergraduate PIM and the students' use of technology and devices in academic pursuits (Mizrachi \& Bates, 2013). While not explicitly looking at PIM, research into the affective and holistic aspects of information search, such as that of Carol Kuhlthau (1999), represent shifts toward experiential information science research that will be consulted in the later stages of this study's theoretical analysis.

Research into academic PIM often draws important connections between information management and the learning process. In the educational context, students are working toward mastery or "ownership" of the information they are exposed to in school, integrating it with previous knowledge (Conley \& French, 2014). The more expertly they demonstrate their individual ability to control or grasp this information, the greater their success against expected student outcomes (Garner, 2010). Some recent studies have turned attention to students' academic PIM experiences and their contextualized information behaviors. For example, undergraduate library and information science (LIS) students were the focus of Finneran's dissertation examining a variety of factors that influence "keeping and leaving" behaviors in the management of academic information (Finneran, 2010). Another study (Pontis et al., 2015), looking at how researchers maintain awareness of new literature and developments in a given field, used an "information journey model" (p. 22) to examine a discrete function of individual academic information management; this is indicative of the move toward broader, more holistic research approaches in academic information studies.

Within the body of LIS research about students and/or researchers, many studies have focused on information literacy and information behaviors, such as the groundbreaking work by Bates and others (Bates, 1996; Mizrachi \& Bates, 2013; Rowlands et al., 2008). Other studies have specifically focused on the research workflow and aspects of personal academic information management behaviors of students and researchers (Finneran, 2010; Habibie, 2015; Jaidka et al., 2013). Library influences on the information skills of beginning researchers has been a focus within the IL domain for some time (Bruce, 2001). Still others beyond LIS have examined the researcher persona and the role of the researcher in scholarly inquiry (Brew, 2001). In fact, defining the researcher's experience and articulating its influence on the design and outcomes of research are common elements of qualitative methodologies (Moch \& Gates, 2000; Roberts, 2007). 
Information literacy models have identified PIM practices as part of the problem-solving process for students, within practices such as information seeking and contextual information retrieval (Eisenberg, 2008). PIM elements are featured in several parts of the "Framework for information literacy for higher education" (Framework for information literacy for higher education, 2016). In the last 20 years, some LIS studies have addressed student information skills and instructional guidance in the individual management of reference data and other research-related information (Fassbender \& Mamtora, 2013; Genoni \& Partridge, 2000; Orna \& Stevens, 1995). These have largely focused on information behavior and IL analysis, many with the goal of informing how libraries might best support information needs and practices in the scholarly workflow (Genoni et al., 2006). Where studies have looked at the broader information experience of students and/or researchers, the research questions have focused on either information literacy (for example, Maybee et al., 2016 and Stonebraker et al., 2019) or information behavior (such as, Limberg, 1999 and Reddy, 2014). To date, there have been no formal studies of research students' individual information experience with academic information management.

Several studies link PIM with the concept of PKM, which can be seen as lifelong "personal enquiry" and related to "personal effectiveness" (Gorman \& Pauleen, 2011, p. 2). In a case study involving both undergraduate and graduate students (Swigon, 2013), personal knowledge and information management were integrated with IL standards to develop a PKIM scale for measuring self-assessment of related skills. Research led by Tenopir and team often employs a behavioral lens and user-centered methods to evaluate academic information phenomena with practical outcomes for the library and publishing communities (Tenopir, Dalton, et al., 2015; Tenopir, King, et al., 2015). In 2008, user interaction methods were applied to articulate affective and cognitive aspects of information seeking behaviors of higher-level students in the hard sciences when searching ScienceDirect (Tenopir et al., 2008). While this and other information science papers demonstrate a wealth of research data about information needs, seeking and use ("INSU") - and some explore the relationship between information use patterns and the learning process (Kari \& Savolainen, 2010) and others illuminate PIM behaviors of upper-level students (Hashemzadeh \& Salehnejad, 2015) there are limited investigations into the holistic PIM practices and contextualized experiences of academic users.

In sum, academic information management, as a phenomenon of study, has been explored in various ways across library and information science literature, particularly focused on information literacy and systems design. As such, the nature of extant research has favored behavioral and skillbased considerations, not adequately illuminating the often private, hidden processes of academic 
information management. Holistic approaches to information management research have been limited and constitute the literature gap addressed by this case illustration.

\section{Information experience}

While not yet appearing in controlled vocabularies of indexing services, such as Library and Information Science Abstracts (LISA), information experience is a concept now addressed alongside established bodies of information science research and theory, such as information behavior and information literacy (Case \& Given, 2016). Now actively driving an evolving body of research, the concept of information experience is open to interpretation and further development, as well as contribution of theory grounded in new exploratory studies and analysis. Assuming "a broad perspective," information experience research aims to capture "an expansive view on people's information life-worlds" (Bruce, Davis, Hughes, Partridge, \& Stoodley, 2014b, p. 10). The aim is not to arrive at generalizable truth, but instead to develop theoretical insights on human-information relationships and portray a rich, contextualized view of people's experiences with "that which informs" (Lupton, 2014, p. 71).

Information Experience: Approaches to Theory and Practice, the seminal 2014 book on the topic, includes reflection from each contributor on the meaning of information experience and the research methods, theories, and constructs developing from this new domain (Bruce, et al., 2014a). Approaches to information experience differ according to the epistemological foundations, perspectives, and experiences of each author. Although phrasing and positions vary, contributing authors discuss their understanding of information experience research as exploring information phenomenon in broad, inclusive, and holistic ways. Some definitions are presented in contrast with the more transactional themes in information behavior research, which largely focus on information acquisition, retrieval, storage, sharing, organization, and other observable aspects of information use. For example, Yates and Partridge see information experience research as providing "a broad understanding and interpretation of people's engagement and interaction with their information environment" (Yates \& Partridge, 2014, p. 122).

Information experience can be approached as a research domain from different theoretical positions, typically seen "through a behavioural, phenomenological or sociocultural lens" (Bruce et al., 2014b, p. 7). The field of information experience research may now be seen to include experiential dimensions of information seeking, use, or literacy models. Information experience may also be regarded as a research focus, situated alongside other research objects, such as information behavior, need, and use - which can also be examined with an experiential lens. In 
addition to a range of theoretical perspectives, information experience researchers have applied a variety of methodological designs to look at information experience in academic contexts.

As outlined in this section, information experience offers a valuable approach to exploring our information encounters as inseparable from the lives of our participants, writ large. In particular, information experience provides a more holistic perspective on research questions that probe matters of information management and encourages us to look beyond transactional or behavioral aspects. Academic information management considered as an information experience will help externalize the often hidden or unnoticed work of academic information management.

\section{Informed learning}

Many information experience studies within the academic domain align with the informed learning framework (Bruce, 2008), which contends that there are "no limits to what we might experience as information," including "many aspects of personal and professional experience, facts, theory, research findings and models, drawings, recipes, interviews, body language, sounds, archival materials, the elements of the natural world as well as the virtual world" (Bruce et al., 2017, p. 6). Informed learning "draws on our understanding of student experiences of using information to learn" (Bruce, 2017, p.5).

This framework is supported by multidisciplinary work on student learning experiences, addressing both how we interact with and use information to learn, as well as self-perceptions and overarching experiences during the learning process. Both the content and the context of learning are key for informed learning research and analysis. Informed learning scholars often cite their work as an alternative to the dominant information literacy approaches that focus on skill acquisition and information behavior.

While this case illustration was not designed to address research questions related to literacies, learning outcomes, and other educational objectives, the close alignment of informed learning (Bruce 2008) and information experience is being considered and will be explored in depth during the advanced stages of theoretical development. The preliminary results presented here anticipate contributions to informed learning and information literacy research, bringing to light the often-unseen practices and untold experiences of academic information management.

\section{Methodology and analysis}

The concept of information experience is central to the research question at hand, what is the student-researcher information experience of academic information management? This research is 
part of an emerging body of information studies that examine information experience as a discrete unit of inquiry, or "research object" (Maybee et al., 2019). Additionally, this study joins other efforts to investigate information experiences of students and others in an academic context; for example, extensive work of this sort has been done in the information literacy domain, some of which are represented in the informed learning discussion above. This case illustration is in good company with information experience researchers using constructivist grounded theory (Davis, 2015; Harlan, 2012; Miller, 2015; Tucker, 2014). The information experience and constructivist approaches share an interest in the subjective perspective and embrace a diverse and dynamic landscape of human experience. In the tradition of information experience research, which "responds to the complexity and change in contemporary society" (Bruce, et al. 2014b, p. 11), this study will be the first to offer a constructivist grounded theoretical portrait of academic information management experiences.

Here, academic information management is considered from the perspective of master's-level social science students in the United States. Utilizing semi-structured qualitative interviews that feature interactive card-sorting activities, the study aims to understand the information experience of these students as they manage information in the course of their graduate work. Hybrid card sorting was used in interviews to allow student-researchers to articulate what informs their master's work and to demonstrate how they identify the academic information they are compelled to manage. Sorting these student-defined cards in response to research questions provided insight into their approaches to and engagement with information management, thereby illuminating their information experience.

\section{Constructivist grounded theory}

Grounded theory "served on the front of the 'qualitative revolution'” (Charmaz, 2000, p. 509) of the 1960s and is now understood to be an ever-evolving research methodology (Morse et al., 2009), or a "constellation of methods" (Charmaz, 2009, p. 128) defined, in part, by variations in epistemological foundation. Constructivist grounded theory was a move away from positivist assumptions of impartiality and employing a more current, interpretive social science approach that avoids isolating a phenomenon from its "social locations" (Charmaz, 2009, p. 146). Constructivist grounded theory is loyal to the inductive, exploratory approach of Glaser and Strauss's classic methodology and is rooted in a subjective approach where "relativism characterizes the research endeavour rather than objective, unproblematic prescriptions and procedures" (Charmaz, 2014, p. 13). 
There is some debate and potential confusion between the terms constructivism and constructionism. Some methodologists observe important distinctions in the claims that knowledge is either individually constructed (constructivism) or socially constructed (constructionism) (Crotty, 1998, p. 58). Constructionists see knowledge as products of social construction, with a focus on community or collective sense-making, whereas constructivists see the individual as the locus of epistemological truth (Andrews, 2012). Constructivism is often seen as a variation that adopts a closer examination of individual knowledge construction (Talja et al., 2005), with the particular intent to ensure social phenomena are considered within subjectivist frameworks, devoid of critical-realist ontological assumptions of a universally knowable reality that is shared by all (Schwandt, 1994).

Constructivists put extra emphasis on the importance of reflexive thinking on the part of the researcher, in order to negotiate the impacts of an investigator's subjective experience and beliefs on the way they carry out their research (Alexander, 2006). With a focus on individual processes and the ways in which language, culture, and other symbols are used in our construction of society and its meanings, constructivist grounded theory is an inductive methodology that strives to develop data-driven theoretical models that explicate human experience (Charmaz 2000, 2014).

Constructivist grounded theory has proven to be appropriate for research into information experience (Davis, 2015; Harlan, 2012; Tucker, 2014). The perspective assumed in this study aligns with the constructivist view that "subjectivity is inseparable from social existence" (Charmaz, 2014, p. 14). Within this philosophical stance, research data was generated via researcher-participant exchanges during interactive interviews, explained in more detail below. The design of this study places information experience at the center of the research question, operating as a sensitizing concept in the grounded theory tradition.

"Constructivist grounded theorists use these [sensitizing] concepts to open inquiry rather than to mold it into a previously established theoretical framework" (Charmaz, 2019, p. 3) As such, information experience influenced the research design and is well aligned with the methodological assumptions outlined above - specifically, those that accept research data will demonstrate multiple, valid realities, mutually constructed in the research process, as captured in a given moment in time. Several information experience studies conducted in recent years demonstrate the belief that there is inherent value in assuming a participant perspective and striving to understand the contextualized individual experience (to name a few: Gorichanaz, 2019; Miller, 2019; Smeaton, Bruce, Hughes, \& Davis, 2017). 
In the case of this study, the aim is to contribute to a more holistic view of student-researchers and broaden our understanding of academic information management, not expecting to develop a grounded theory that represents a generalizable truth to be universally known or recognized by all student-researchers everywhere. Instead, the outcomes of this study will offer one researcher's rendering of the participants' perspectives grounded in their information experience and contribute to the wider effort to understand academic information management holistically.

\section{Interactive interviews}

As demonstrated above, constructivist grounded theory studies that explore information experience as the research focus operate with the assumption that there is unique meaning to be derived from adopting this perspective, yet it does not dictate the use of specific data generation techniques. This study designed interactive interviews in a manner that aligns with constructivist grounded theory principles - namely, the avoidance of researcher-imposed language and worldviews - and information experience principles, such as the expectations that information may be subjectively defined and perceived. Additionally, this technique is well aligned with the codevelopment of meaning and shared understandings understood to be key to conducting constructivist grounded theory research (Charmaz \& Mitchell, 1996). "We view the method itself as an emergent construction in which our subjectivity is embedded in how we use the method as well as create the analysis" (Charmaz, 2019, p. 5).

Semi-structured qualitative interviews, enhanced by hybrid card-sorting activities, was the central method used in this study. Without defining academic information or what constitutes its management, the interviews prompted student-researchers to reflect on that which informs their graduate work. In the first half of each interview, participants were asked to label cards with the information they believe is relevant to achieving their master's degree. Each unique set of cards was then used in interactive sorting activities during the second half of the session; cards were sorted in answer to interview questions addressing the student's relationship with academic information and the ways in which their motivations, priorities, fears, and ambitions influence their management of that information.

These interactive interviews were conducted with 12 student-researchers, with blank cards used to generate the academic information relevant to each individual participant. These cards became the focus of each conversation with students, seen as expressions of their information experience in managing academic information. Entering into these interviews without imposing pre-conceived notions of what constitutes academic information and what entails its management 
was inspired by the methodological guidance from Charmaz: "if you attend to your participants' language, you can bridge their experience with your research questions" (2014, p. 100). "Card sorting is well suited to research questions that explore emerging fields or new theoretical constructs, where topics are not easily described or are not yet well defined in the literature" (Conrad \& Tucker, 2019, p. 411).

Capturing student-researchers' original card label early in each interview allowed for exploration of interview questions with sorting exercises, successfully rendering abstract or complicated concepts in a tangible format for analytical co-development. In this way, interactive interviews served as a method of "investigating information-as-it-is-experienced" which "takes the person as the starting point" (Lupton, 2014, p. 73). Card sorting allowed students to define the scope of the interview and externalize hidden systems, allowing both researcher and participant to evaluate the complex meanings and relationships at hand.

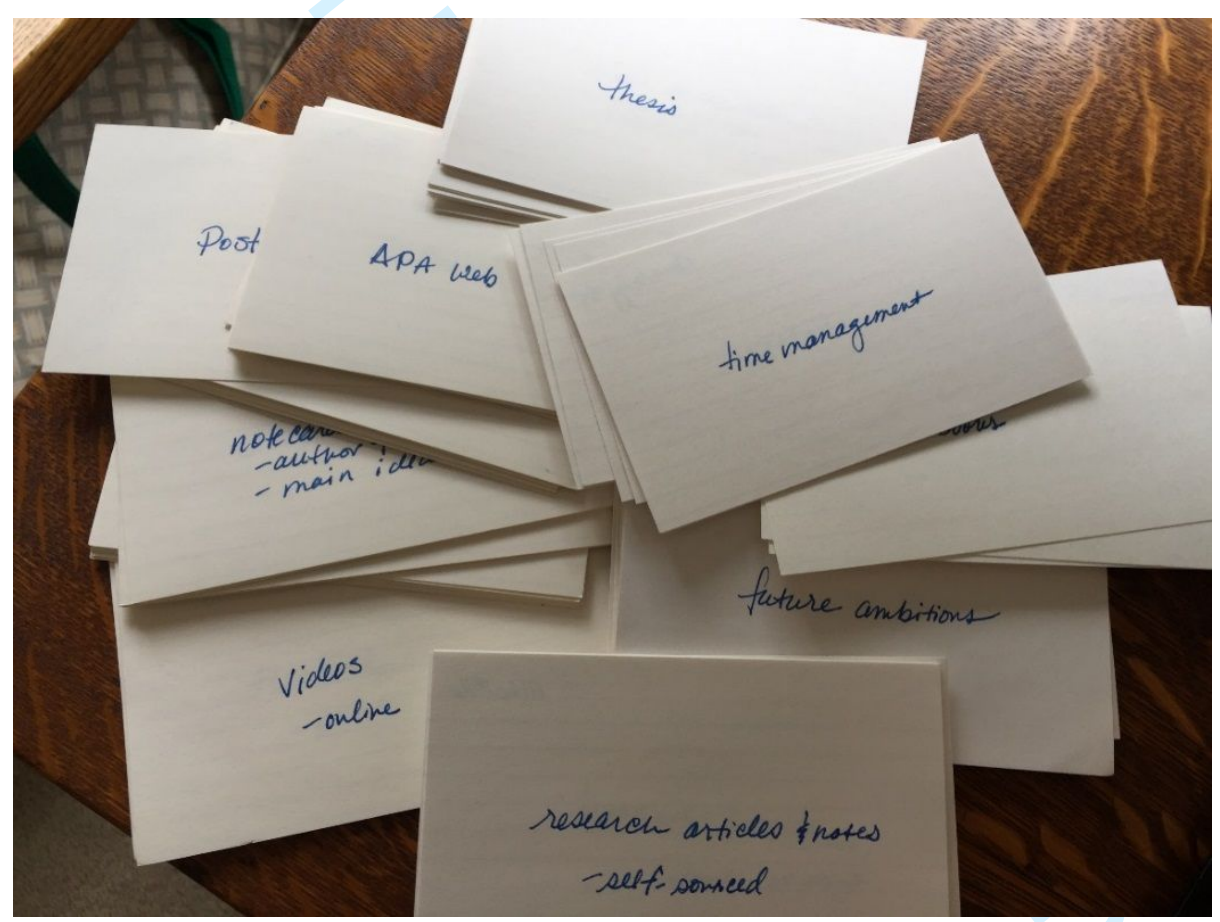

Figure 1: Cards labelled by student-researchers with 'that which informs' their masters' work

\section{Participant profiles}

Student-researchers were recruited from social science programs at a small private university in the United States. A recruiting questionnaire was distributed to document participant consent, age, enrollment status, and qualifications. A student-researcher is defined as a scholar-in-training with the following characteristics:

- $\quad$ enrolled in a master's-level program (or equivalent) 
- conducting supervised original academic research in social science

- learning how to execute scholarly inquiry practices for the first time

- will produce traditional scholarly output, such as a thesis with literature review

Participants with this profile are in an ideal position to demonstrate a broad range of research student experiences with managing academic information in a personal domain. This study was designed to limit participants to similar fields that require theses with literature reviews. By focusing on social science masters' students, the goal is to illuminate diverse academic information management practices within a manageable dataset of readily comparable information experiences.

Interviews lasted 60-90 minutes and were audio recorded, card sorting results were photographed, and integrated transcripts with both interview dialogue, original card labels, and sorting results were generated for each participant. All participant data was fully anonymized and personally identifiable data are secured per institutional ethics and data management requirements. Throughout the forthcoming presentation and discussion of findings, participants will be referred to using their first-name pseudonyms. See high-level profiles for the 12 participating student-researchers in Appendix I.

\section{The student-researcher information experience}

Under the guiding framework of constructivist grounded theory methodology, at the time of writing, this study was entering later stages of analysis and early articulation of some initial findings. As constructivist research, where "data are narrative constructions of experience" (Charmaz, 2000, p. 514), analysis in this study will generate a theoretical rendition of studentresearchers' information experience with academic information management. Early sense-making in this study suggests thematic trends in what information experience researchers using constructivist grounded theory might gain when looking beyond the observable, measurable outcomes of academic information management.

Three initial categories reflect how student-researchers relate to and experience academic information management: (i) what they perceive as information; (ii) how they determine what information requires their individual management, and (iii) what strategies they develop for achieving those management practices. These categories were developed during first and second coding cycles, where coding was performed across the 12 interviews, six of which were coded lineby-line, analyzing the transcripts, card labels, and card-sorting data in parallel. Table 1 presents a sampling of in vivo codes developed during this analysis, where illustrative quotes became emblematic of ways student-researchers perceive and relate to academic information management. 
Characteristic of constructivist grounded theory, in vivo codes capture participant language and phrases that "reflect assumptions, actions, and imperatives that frame [participant] action" (Charmaz, 2014, p. 135).

Table 1: Illustrative quotes \& codes assigned to initial categories

\begin{tabular}{|l|l|l|l|}
\hline \multicolumn{1}{|c|}{$\begin{array}{c}\text { What student- } \\
\text { researchers perceive as } \\
\text { information }\end{array}$} & $\begin{array}{c}\text { How student-researchers } \\
\text { determine what } \\
\text { information requires } \\
\text { individual management }\end{array}$ & $\begin{array}{r}\text { What strategies student- } \\
\text { researchers develop for } \\
\text { achieving academic } \\
\text { information management }\end{array}$ \\
\hline Mac & "Something I can trust" & "Digesting...core knowledge" & "Make outlines of every article" \\
\hline Jack & "Hoops to jump" & "Means to an end" & "A very contained system" \\
\hline Katie & $\begin{array}{l}\text { "Class discussion \& } \\
\text { participation" }\end{array}$ & "I'm passionate about it" & "Theory to practice" \\
\hline Tori & "Mersonal experience" & "My own personal growth" & "Break it up into manageable chunks" \\
\hline Tom & "My database" & "Having an impact" & "I'm a dedicate-the-day girl" \\
\hline
\end{tabular}

Student-researchers volunteered original labels for the cards used during interactive interviews that include the type of informational assets one might expect in this study - such as "literature review" and "lectures" - as well as some surprising concepts - such as "disabled students services," "peer support," and a range of professional development activities. The information represented on students' original cards are emblematic of the ways in which each participant understands or frames their academic experience, informed by cultural influences as well as personal mindset, identity, and motivations.

The ways that student-researchers define or perceive academic information and their management of it involve adaptative, interpretive practices. The student-researcher information experience with academic information management is shaped by each participant's personal interpretations of and relationships to the information in their broader academic life-worlds. More specifically, adaptive strategies are developed and deployed as needed to manage academic information in order to fulfill a given objective, goal, or expectation perceived as valuable in their academic journeys. For example, Tom (participant pseudonym) characterizes his academic information management as a product of "trial and error ... just learning how I learn." When asked to explain his sorting of cards based on levels of difficulty or stress, Mac explained that he manages academic information differently when "it just comes naturally to me" or when "expectations are low." 
Adaptive strategies in academic information management range from the operational, such as tactics for time management and reading retention; for instance, when Julia describes her use of a printed, bound organizer, she says "I find that actually writing things down helps a lot." The testing and refinement of information management techniques occurs almost instinctually, as studentresearchers learn what allows them to successfully integrate new terminology into their vocabulary or engage with new concepts. Melony explains that she has learned that "breaking it down" into "manageable chunks" helps her complete her assignments on time.

These adaptive strategies, and the interpretations and motivating forces that drive their formation, are often influenced by how student-researchers relate to the information and information-management experiences involved in their academic pursuits. These relationships include elements such as attitudes, identity, risk, motivations, culture, and more - all of which speak to the broad, fluid nature of human experience, and none of which can be easily classified as purely behavioral, cognitive, affective, or socio-cultural. Instead, preliminary analysis suggests that student-researcher relationships with academic information and its management are a complex recipe that cooks up different aspects of information experience, as situations and circumstances change throughout the educational process.

Adaptive strategies also include nuanced, intellectual and analytical interactions, where students negotiate fears and navigate identities in the course of managing academic information. Some students discussed strategies that were adapting to their emotional responses or cognitive limitations. Tori described her work to manage stress and said she's "calm in control," thus her love of post-it notes, calendar reminders, and multiple cloud back-ups of her work. Katie spoke about recovering from a concussion and seeking out campus resources to help her with reading, retention, and test taking. Managing their focused attention and concentration, with pragmatic, affective, and intellectual strategies, was a theme throughout student-researcher interviews.

While cultural, organizational, and other community-based influences are relevant in this context, several observations point to the highly individual nature of personal information management in academic endeavors. The contextualized relationships with academic information and the resulting strategies developed to manage academic information are rooted in studentresearchers' sense of self. In fact, the iterative and adaptive nature of information management within the learning experience can be seen as a process of negotiating and navigating changes to students' identity. Whether intentional or not, information management strategies are expressions of the student-researcher's personal ambitions, identity, mindset, and other such elements - 
expressions that range from the logistical - "I'm a visual learner" (Tori) - to the methodological "I'm a stats person" (Jack) - to the emotional - "I hate research" (Melony).

In this study, information management is understood to be as a fluid stream of experiences to be viewed holistically within a subjective context, understood to be ever in motion and operating as adaptive, interpretative devices. Viewed as information experiences, academic information management in this study is seen as not only involving organizational practices, but is ultimately a process of individualizing - whereby, student-researchers personally orchestrate their learning experiences and curate the academic information they are compelled to manage. As analysis continues in this project, these observations will be further developed using the constructivist grounded theory techniques of theoretical sampling and secondary literature reviews, to move these outcomes toward theory formation.

\section{Discussion and implications}

This paper discusses how the work in question contributes to our understanding of how information experience research provides unique insights into information management phenomena. Asking the question, what is the student-researcher information experience of academic information management, this study may broaden our understanding of academic information management and the wider field of information management, offering new perspectives to that area of study. Building upon insights from the research traditions of information literacy and information behavior, this information experience study will produce findings that extend our view of how student-researchers experience academic information.

Additionally, we expect outcomes will contribute to the emerging field of information experience, suggesting this approach offers a unifying model to achieve a holistic view of human encounters with information. These outcomes will offer instructors, librarians, and systems designers new insights into the often-unnoticed information experience of academic information management, which can be seen as integral to academic success. At the time of writing, the constructivist grounded theory illustration featured in this paper had not yet reached the stage of theoretical sampling and secondary literature review, therefore a future paper will be needed to outline the final theoretical conclusions and contributions to the field of information management.

\section{Constructivist view of information experience}

The preliminary categories discussed above - (i) what student-researchers perceive as information; (ii) how they determine what information requires individual management; and (iii) 
what strategies they develop for achieving academic information management -- are indicative of analytical outcomes where information experience acts as the research focus in a constructivist grounded theory study. In this case, information experience is at the core of the research question, informing the assumptions that drove the research design. These initial categories are indicative of information experience research in that they embrace fluid, subjective, and holistic perspectives on student-researchers' relationships with and experiences of academic information management.

As expected within a constructivist study, the forthcoming grounded theory will be a byproduct of the researcher's observations and interpretations of the data generated in this study (Charmaz, 2014, pp. 225-260). In other words, this study will produce an analytical rendering of studentresearchers' own interpretations of their information experience with managing academic information. Understanding the data to reflect student-researchers' constructed experiences at the time of the interactive interviews, theoretical outcomes will deconstruct the processes and meanings inherent in participants' information experience with academic information management. It is expected that the resulting grounded theory will present the concept of information experience as a distinct entity - not as an object to be known universally, but as a holistic model to help fill gaps in our understanding of the phenomenon.

Using constructivist grounded theory to investigate information experience enables embracing the multiple, constructed realities involved in human experience, viewed as a series of actions and processes that assign meaning to the world around us. This approach understands information and our encounters with it to be heavily contextualized - where our relationships with information and the meanings we impose on that information are highly dependent upon the situation at hand, allowing for myriad influences on our experiences with information. These are not static or fixed influences, of course, as we understand experience to be constantly in motion and ever evolving. Information experiences are being written and rewritten with each new moment - as memories are conjured and new experiences unfold, we are already changing that information experience, as well as what meanings or interpretations are derived from it.

Additionally, this approach understands information experiences to be subjective, where we cannot consider these contextualized relationships with information without considering the broader view of an individual person's or group's situated realities. The goal is not to generate a universal theory for a given population, but instead to flesh out the wider understanding of information experiences with humanistic perspectives. In this way, information management is seen as a fluid stream of experiences, as expressed in a fixed moment in time, and viewed 
holistically within a subjective context, understood to be ever in motion, as both an interpretation and in need of interpretation.

\section{Information experience as unifying concept}

As exemplified by the research outlined in this paper, the constructivist view of information experience sees inherent value in adopting a wider lens on information research questions, allowing researchers to incorporate a broad array of human realities in our analytical considerations. This approach to information science sees our information experiences as inseparable from the totality of our life experiences - or, in phenomenological terms, our lifeworlds. This unifying approach understands that information and information experiences are not best defined by a third party, i.e. the researcher, but we instead aim to view a given phenomenon from the perspective of the participants. This approach challenges researchers to assume subjective positions, as we aim to approach our research questions from the viewpoint of our target population and, as much as is possible, suspend our external assumptions or operational definitions in order to make room for the situated perspectives of our participants.

Similarly, constructivist information experience research does not enter into a given study with a presumed result or end goal in mind, such as the organizational practices of file storage or retrieval in information management. We do not assume we know participants' goals and intentions, and therefore do not enter into a study with expectations for specific behaviors, skills, or tasks. These transactional aspects are, of course, still very relevant to information experience research and should be considered as part of the whole picture; however, they are not the prevailing focus or objective.

Therefore, information experience allows us to zoom out and widen our perspective, to evaluate research questions at a more inclusive scale - for example, to incorporate transactional and behavioral elements of academic information management (citing, organizing, retrieval, etc.) with a host of other considerations (identity, ambition, mindset, and more). While information studies successfully examine discrete aspects of information phenomena, these can be brought together in an experiential framework. Bringing holistic elements together offers information management research a wider lens to make sense of discrete units of inquiry while painting a fuller picture of the human information experience. Adopting a wide lens with information experience means we define our scope of research as the multi-dimensional information journey, as expressed in a given moment in time, incorporating a range of elements into our understanding of the topic at hand. 


\section{Limitations}

As explained above, information experience is an emerging domain of research and practice, so there is much work yet to be done to develop the domain further. This project is among a small circle of constructivist grounded theory studies investigating questions with information experience as a focus of research, and the only known study of its kind focused on academic information management. Additionally, this study will develop grounded theory on academic information management based upon one situated masters-level student perspective in the United States; the wider scope of this phenomenon should consider other regions, institutions, developmental levels, and various contextualized instances of the academic information experience. Therefore, with the customarily small sample size of a qualitative doctoral study, there are known limitations in this endeavor, which call for ongoing constructivist grounded theory research using the information experience domain. As is true for any constructivist grounded theory study, the researcher's subjective influences before and during the execution of a study are recorded in reflexive memo-writing (see Appendix II) to inform these limitations.

\section{Conclusion}

The concept of information experience has potential to offer a wider lens for information research by aiming to understand "complex, multidimensional engagement with information" (Bruce, et al., 2014b, p. 10). As illustrated with this study, using constructivist grounded theory to examine information experience has the capacity to extend our awareness of underlying meanings of and relationships with information, specifically academic information management. The constructivist framework supports the philosophical assumptions that multiple valid realities coexist in any given information phenomenon and that information experiences are inextricable from our broader life experiences. In addition to methodological contributions, expected outcomes of this study will offer instructors, librarians, and systems designers a more holistic view of the information experience of academic information management. 


\section{Appendix I}

This table summarizes participant profiles using self-identified demographic detail and key points of observation about the 12 student-researchers in this study.

Table 2: Participant profiles

\begin{tabular}{|c|c|c|c|c|c|c|c|}
\hline No. & Pseudonym & Gender & Age & Field of study & $\begin{array}{l}\text { Thesis } \\
\text { status }\end{array}$ & Work status & Future plans \\
\hline 1 & Melony & Female & $18-24$ & $\begin{array}{l}\text { Education, } \\
\mathrm{K}-12 \text { teaching }\end{array}$ & $\begin{array}{l}\text { In progress } \\
\text { (required) }\end{array}$ & $\begin{array}{l}\text { Part-time } \\
\text { (outside field) }\end{array}$ & $\begin{array}{l}\text { Practitioner career } \\
\text { path }\end{array}$ \\
\hline 3 & Tori & Female & $25-34$ & $\begin{array}{l}\text { Education, } \\
\text { K-12 teaching }\end{array}$ & $\begin{array}{l}\text { In progress } \\
\text { (required) }\end{array}$ & $\begin{array}{l}\text { Full-time } \\
\text { (in field) }\end{array}$ & $\begin{array}{l}\text { Long-term } \\
\text { academic goals }\end{array}$ \\
\hline 5 & Brenda & Female & $25-34$ & $\begin{array}{l}\text { Education, } \\
\text { K-12 teaching }\end{array}$ & $\begin{array}{l}\text { In progress } \\
\text { (required) }\end{array}$ & $\begin{array}{l}\text { Full-time } \\
\text { (in field) }\end{array}$ & Unsure \\
\hline 6 & Robin & Female & $18-24$ & $\begin{array}{l}\text { Education, } \\
\text { K-12 teaching }\end{array}$ & $\begin{array}{l}\text { In progress } \\
\text { (required) }\end{array}$ & $\begin{array}{l}\text { Full-time } \\
\text { (in field) }\end{array}$ & $\begin{array}{l}\text { Practitioner career } \\
\text { path }\end{array}$ \\
\hline 8 & Jack & Male & $25-34$ & $\begin{array}{l}\text { Education, } \\
\text { K-12 teaching }\end{array}$ & $\begin{array}{l}\text { In progress } \\
\text { (required) }\end{array}$ & $\begin{array}{l}\text { Full-time } \\
\text { (in field) }\end{array}$ & $\begin{array}{l}\text { Practitioner career } \\
\text { path }\end{array}$ \\
\hline 11 & Tom & Male & $25-34$ & $\begin{array}{l}\text { Business, public } \\
\text { admin. }\end{array}$ & $\begin{array}{l}\text { In progress } \\
\text { (optional) }\end{array}$ & $\begin{array}{l}\text { Full-time } \\
\text { (in field) }\end{array}$ & Unsure \\
\hline 12 & Katie & Female & $18-24$ & $\begin{array}{l}\text { Education, } \\
\text { counseling }\end{array}$ & $\begin{array}{l}\text { In progress } \\
\text { (optional) }\end{array}$ & $\begin{array}{l}\text { Full-time } \\
\text { (in field) }\end{array}$ & Unsure \\
\hline 14 & Julia & Female & $18-24$ & $\begin{array}{l}\text { Education, } \\
\text { K-12 teaching }\end{array}$ & $\begin{array}{l}\text { In progress } \\
\text { (required) }\end{array}$ & $\begin{array}{l}\text { Full-time } \\
\text { (in field) }\end{array}$ & $\begin{array}{l}\text { Practitioner career } \\
\text { path }\end{array}$ \\
\hline 15 & Courtney & Female & $25-34$ & $\begin{array}{l}\text { Education, } \\
\text { counseling }\end{array}$ & $\begin{array}{l}\text { In progress } \\
\text { (optional) }\end{array}$ & $\begin{array}{l}\text { Full-time } \\
\text { (in field) }\end{array}$ & Unsure \\
\hline 16 & Mac & Male & $18-24$ & $\begin{array}{l}\text { Psychology, } \\
\text { clinical }\end{array}$ & $\begin{array}{l}\text { In progress } \\
\text { (optional) }\end{array}$ & $\begin{array}{l}\text { Full-time } \\
\text { (in field) }\end{array}$ & $\begin{array}{l}\text { Doctoral goals, } \\
\text { clinical career path }\end{array}$ \\
\hline
\end{tabular}




\begin{tabular}{|l|l|l|l|l|l|l|l|}
\hline 17 & Mary & Female & $45-54$ & $\begin{array}{l}\text { Education, } \\
\text { counseling }\end{array}$ & $\begin{array}{l}\text { In progress } \\
\text { (optional) }\end{array}$ & $\begin{array}{l}\text { Full-time } \\
\text { (in field) }\end{array}$ & Unsure \\
\hline 18 & Butch & Male & $25-34$ & $\begin{array}{l}\text { Psychology, } \\
\text { clinical }\end{array}$ & $\begin{array}{l}\text { In progress } \\
\text { (optional) }\end{array}$ & $\begin{array}{l}\text { Full-time } \\
\text { (in field) }\end{array}$ & $\begin{array}{l}\text { Doctoral goals, } \\
\text { clinical career path }\end{array}$ \\
\hline
\end{tabular}

\section{Appendix II}

\section{Reflexive statement}

Among various devices to ensure rigorous, high-quality qualitative analysis, constructivist grounded theory methodology advises researchers to practice reflexive memo-writing and selfreflection. Understanding knowledge and meaning to be constructed via social interactions and interpretations, constructivism expects the researcher to present their position and assumptions about their research topic(s), and to regularly reflect upon these subjective influences during the execution of research projects. As such, the following statement is submitted within the context of this study and analytical discussions.

The primary researcher leading this study, Lettie Y. Conrad, is an information science doctoral candidate at Queensland University of Technology in the San José PhD Gateway program. Conrad brings perspectives from her education in philosophy and mass communications, as well as many years of experience as a publishing and product development consultant to scholarly content and technology providers. Motivation to pursue a study of academic information management largely stems from this professional research and development background. In both her academic and practitioner capacities, Conrad's research agenda is focused on serving the evolving needs of researchers and scientists, in order to facilitate optimum information experiences for today's scholars.

\section{References}

Alexander, H. A. (2006), "A view from somewhere: Explaining the paradigms of educational research," Journal of Philosophy of Education, Vol. 40 No. 2, pp. 205-221.

Al-Omar, M., \& Cox, A. (2013), "Finders, Keepers, Losers, Seekers: A Study of Academics' Research-Related Personal Information Collections," in S. Yamamoto (Ed.), Human Interface and the Management of Information, Lecture Notes in Computer Science, Vol. 8016, Springer, Berlin, pp. 169-176. 
Andrews, T. (2012), "What is social constructionism?," Grounded Theory Review, Vol. 11 No. 1.

Association of College and Research Libraries (2016), "Framework for information literacy for higher education," available at

http://www.ala.org/acrl/sites/ala.org.acrl/files/content/issues/infolit/framework1.pdf (accessed 6 November 2019).

Bates, M. J. (1996), "Learning about the information seeking of interdisciplinary scholars and students," Library Trends, Vol. 45 No. 2, pp. 155-164.

Bowen, G. A. (2006), "Grounded theory and sensitizing concepts," International Journal of Qualitative Methods, Vol. 5 No. 3, pp. 12-23.

Brew, A. (2001), The nature of research: Inquiry in academic contexts, Routledge Falmer, New York, NY.

Bruce, C. (2001), "Interpreting the scope of their literature reviews: Significant differences in research students' concerns," New Library World, Vol. 102 No. 4/5, pp. 158-166.

Bruce, C. S. (2008), Informed learning, American Library Association, Chicago, IL.

Bruce, C. S., Davis, K., Hughes, H., Partridge, H. L., \& Stoodley, I. (2014a), Information experience: Approaches to theory and practice, Emerald Group Publishing Ltd, Bingley, UK.

Bruce, C. S., Davis, K., Hughes, H., Partridge, H. L., \& Stoodley, I. (2014b), "Information experience: Contemporary perspectives," in Bruce, C. S., et al. (Eds), Information Experience: Approaches to Theory and Practice, Emerald Group Publishing Ltd, Bingley, UK, pp. 3-15.

Bruce, C. S., Demasson, A., Hughes, H., Lupton, M., Sayyad Abdi, E., Maybee, C., Somerville, M. M., \& Mirijamdotter, A. (2017), "Information literacy and informed learning: Conceptual innovations for IL research and practice futures," Journal of Information Literacy, 11(1), 4. https://doi.org/10.11645/11.1.2184

Case, D. O., \& Given, L. M. (2016), Looking for Information: A Survey of Research on Information Seeking, Needs, and Behavior, Emerald Group Publishing Ltd, Bingley, UK.

Charmaz, K. (2000), "Grounded theory: Objectivist and constructivist methods," in Denzin N. and Lincoln Y. (Eds), Handbook of qualitative research (2nd ed), SAGE Publications Inc., Thousand Oaks, CA, pp. 509-536.

Charmaz, K. (2009), "Shifting the grounds: Constructivist grounded theory methods," in Morse, J. M., et al. (Eds), Developing Grounded Theory: The Second Generation, Left Coast Press Inc., Walnut Creek, CA, pp. 127-147. 
Charmaz, K. (2014), Constructing grounded theory, 2nd edition, SAGE Publications, Ltd., London, UK.

Charmaz, K. (2019), "'With Constructivist Grounded Theory You Can't Hide': Social Justice Research and Critical Inquiry in the Public Sphere," Qualitative Inquiry, https://doi.org/10.1177/1077800419879081.

Charmaz, K., \& Mitchell, R. G. (1996), "The Myth of Silent Authorship: Self, Substance, and Style in Ethnographic Writing," Symbolic Interaction, Vol. 19 No. 4, pp. 285-302.

Conley, D. T., \& French, E. M. (2014), "Student ownership of learning as a key component of college readiness," American Behavioral Scientist, Vol. 58 No. 8, pp. 1018-1034.

Conrad, L. Y., \& Tucker, V. M. (2019), "Making it tangible: Hybrid card sorting within qualitative interviews," Journal of Documentation, Vol. 75 No. 2, pp. 397-416.

Crotty, M. (1998), The foundations of social research: Meaning and perspective in the research process, SAGE Publications Inc., Thousand Oaks, CA.

Davis, K. (2015), "The information experience of new mothers in social media: A grounded theory study," Doctoral dissertation, Queensland University of Technology, Brisbane, AU.

Diekema, A. R., \& Olsen, M. W. (2014), "Teacher personal information management (PIM) practices: Finding, keeping, and re-finding information," Journal of the Association for Information Science and Technology, Vol. 65 No. 11, pp. 2261-2277.

Eisenberg, M. (2008), "Personal Information Management," presented at the University of Washington, available at http://faculty.washington.edu/mbe/M\%20Eisenberg\%20on\%20PIM\%202008.pdf (accessed 6 November 2019).

Fassbender, E., \& Mamtora, J. (2013), "A workflow for managing information for research using the iPad, Sente and Dragon Dictate: A collaboration between an academic and a research librarian," Australian Library Journal, Vol. 62 No. 1, pp. 53-60.

Finneran, C. M. (2010), "Factors that influence users to keep and leave information items: A case study of college students' personal information management behavior," doctoral dissertation, Syracuse University, New York, NY.

Garner, S. (2010), "Personal knowledge management and student learning," Journal of Business \& Economics Research, Vol. 8 No. 12, pp. 43-47. 
Genoni, P., Merrick, H., \& Willson, M. A. (2006), "Scholarly communities, e-research literacy and the academic librarian," The Electronic Library, Vol. 24 No. 6, pp. 734-746.

Genoni, P., \& Partridge, J. (2000), "Personal research information management: Information literacy and the research student," in C. S. Bruce, P. C. Candy, \& H. Klaus (Eds.), Information literacy around the world: Advances in programs and research, Centre for Information Studies, Charles Sturt University, New South Wales, pp. 223-235.

Gorichanaz, T. (2019), "Information experience in personally meaningful activities," Journal of the Association for Information Science and Technology, Vol. 70 No. 12, pp. 1302-1310.

Gorman, G. E., \& Pauleen, D. J. (2011), "The nature and value of personal knowledge management," in Pauleen, D. J. and Gorman, G. E. (Eds), Personal Knowledge Management: Individual, organizational and social perspectives, Routledge, New York, NY, pp. 1-16.

Habibie, P. (2015), "An investigation into writing for scholarly publication by novice scholars: Practices of canadian anglophone doctoral students," doctoral dissertation, University of Western Ontario, Canada.

Harlan, M. A. (2012), "Information practices of teen content creators: The intersection of action and experiences a grounded theory study," doctoral dissertation, Queensland University of Technology, Brisbane, AU.

Hashemzadeh, M. J., \& Salehnejad, Z. (2015), "Personal information management behavior among postgraduate students of University of Birjand," presented at Emerging Trends and Technologies in Libraries and Information Services (ETTLIS), 4th International Symposium, IEEE, pp. 307-311.

Jaidka, K., Khoo, C. S. G., \& Na, J. (2013), "Literature review writing: How information is selected and transformed," Aslib Proceedings, Vol. 65 No. 3, pp, 303-325.

Jones, W. P. (2012), The future of personal information management. Pt. 1: Our information, always and forever, Morgan \& Claypool, San Rafael, CA.

Jones, W. P., \& Teevan, J. (2011), Personal information management, University of Washington, Press Seattle, WA.

Kari, J., \& Savolainen, R. (2010), "On the connections between information use and learning process," in C. S. Bruce, P. C. Candy, \& H. Klaus (Eds.), Information literacy around the world: Advances in programs and research, Centre for Information Studies, Charles Sturt University, New South Wale, pp. 229-249. 
Kuhlthau, C. (1999), "The role of experience in the information search process of an early career information worker: Perceptions of uncertainty, complexity, construction, and sources," Journal of the American Society for Information Science, Vol. 50 No. 5, pp. 399-412.

Limberg, L. (1999), "Experiencing information seeking and learning: A study of the interaction between two phenomena," Information Research, Vol. 5 No. 1.

Lupton, M. (2014), "Creating and expressing: Information as-it-is-experienced, in Bruce, C. S., et al. (Eds), Information Experience: Approaches to Theory and Practice, Emerald Group Publishing Ltd, Bingley, UK, pp. 69-83.

Maybee, C., Abdi, E. S., Davis, K., \& Conrad, L. (2019), "Information experience: A domain and object of study," Proceedings of the Association for Information Science and Technology, Vol. 56 No. 1, pp. 550-553.

Maybee, C., Bruce, C. S., Lupton, M., \& Rebmann, K. (2016), "Designing rich information experiences to shape learning outcomes," Studies in Higher Education, Vol. 42 No. 12, pp. 116.

Miller, F. Q. (2015), “Experiencing information use for early career academics' learning: A knowledge ecosystem model," Journal of Documentation, Vol. 71 No. 6, pp. 1228-1249.

Miller, F. Q. (2019), "Encountering relatable information in experiential learning spaces: A partnership framework for research information specialists and early career researchers," Journal of Documentation, Vol. 75 No. 3, pp. 517-529.

Mizrachi, D., \& Bates, M. J. (2013). “Undergraduates' personal academic information management and the consideration of time and task-urgency," Journal of the American Society for Information Science and Technology, Vol. 64 No. 8, pp. 1590-1607.

Moch, S. D., \& Gates, M. F. (2000), "Introduction: What about the researcher experience?," in Moch, S. D. and Gates M. F. (Eds), "The Researcher Experience in Qualitative Research," SAGE Publications, Inc., Thousand Oaks, CA, pp. 3-6.

Morse, J. M., Stern, P. N., Corbin, J., Bowers, B., Schatzman, L., Charmaz, K., \& Clarke, A. E. (2009), Developing grounded theory: The second generation. Left Coast Press, Inc., Walnut Creek, CA.

Orna, E., \& Stevens, G. (1995), Managing information for research, Open University Press, Maidenhead, UK.

Osae Otopah, F., \& Dadzie, P. (2013), "Personal information management practices of students and its implications for library services," Aslib Proceedings, Vol. 65 No.2, pp. 143-160. 
Pontis, S., Blandford, A., Greifeneder, E., Attalla, H., \& Neal, D. (2015), "Keeping up to date: An academic researcher's information journey," Journal of the Association for Information Science and Technology, Vol 1 No. 14.

Reddy, V. (2014), "Information Experience in the Context of Information Seeking Methods by Prospective Students," in Bruce, C. S., et al. (Eds), Information Experience: Approaches to Theory and Practice, Emerald Group Publishing Ltd, Bingley, UK, pp. 295-312.

Roberts, B. (Ed.). (2007), "Conclusion: The researcher's experience of research," in Getting the Most Out of the Research Experience, SAGE Publications, London, UK, Ltd., pp. 144-153.

Rowlands, I., Nicholas, D., Williams, P., Huntington, P., Fieldhouse, M., Gunter, B., Tenopir, C. (2008), "The Google generation: The information behaviour of the researcher of the future," Aslib Proceedings, Vol. 60 No.4, pp. 290-310.

Schwandt, T. A. (1994), "Constructivist, interpretivist approaches to human inquiry, in Denzin N. and Lincoln Y. S. (Eds.), Handbook of qualitative research, SAGE Publications Inc., Thousand Oaks, CA.

Smeaton, K., Bruce, C., Hughes, H., \& Davis, K. (2017), "The online life of individuals experiencing socioeconomic disadvantage: How do they experience information?," Information Research, Vol. 22 No. 3.

Stonebraker, I., Maybee, C., \& Chapman, J. (2019), “Undergraduate students' experiences of using information at the career fair: A phenomenographic study conducted by the libraries and career center," The Journal of Academic Librarianship, Vol. 45 No. 4, pp. 358-367.

Swigon, M. (2013), "Personal knowledge and information management-Conception and exemplification," Journal of Information Science, Vol. 39 No. 6, pp. 832-845.

Talja, S., Tuominen, K., \& Savolainen, R. (2005), "'Isms' in information science: Constructivism, collectivism and constructionism," Journal of Documentation, Vol 61 No.1, pp. 79-101.

Tang, R., Mehra, B., Du, J. T., \& Zhao, Y. (2019), "Paradigm shift in information research," Proceedings of the Association for Information Science and Technology, Vol. 56 No. 1, pp. 578581.

Tenopir, C., Dalton, E. D., Allard, S., Frame, M., Pjesivac, I., Birch, B., Dorsett, K. (2015), "Changes in data sharing and data reuse practices and perceptions among scientists worldwide," PLOS ONE, Vol. 10 No. 8, e0134826.

Tenopir, C., King, D. W., Christian, L., \& Volentine, R. (2015), "Scholarly article seeking, reading, and use: A continuing evolution from print to electronic in the sciences and social sciences," Learned Publishing, Vol. 28 No. 2, pp. 93-105. 
Tenopir, C., Wang, P., Zhang, Y., Simmons, B., \& Pollard, R. (2008), “Academic users' interactions with ScienceDirect in search tasks: Affective and cognitive behaviors," Information Processing \& Management, Vol. 44 No. 1, pp. 105-121.

Tucker, V. M. (2012), "Acquiring search expertise: Learning experiences and threshold concepts," doctoral dissertation, Queensland University of Technology, Brisbane, AU.

Tucker, V. M. (2014), “The expert searcher's experience of information," in Bruce, C. S., et al. (Eds), Information Experience: Approaches to Theory and Practice, Emerald Group Publishing Ltd, Bingley, UK, pp. 239-254.

Yates, C., \& Partridge, H. (2014), "Exploring information literacy during a natural disaster: The 2011 Brisbane flood," in Bruce, C. S., et al. (Eds), Information Experience: Approaches to Theory and Practice, Emerald Group Publishing Ltd, Bingley, UK, pp. 119-133. 


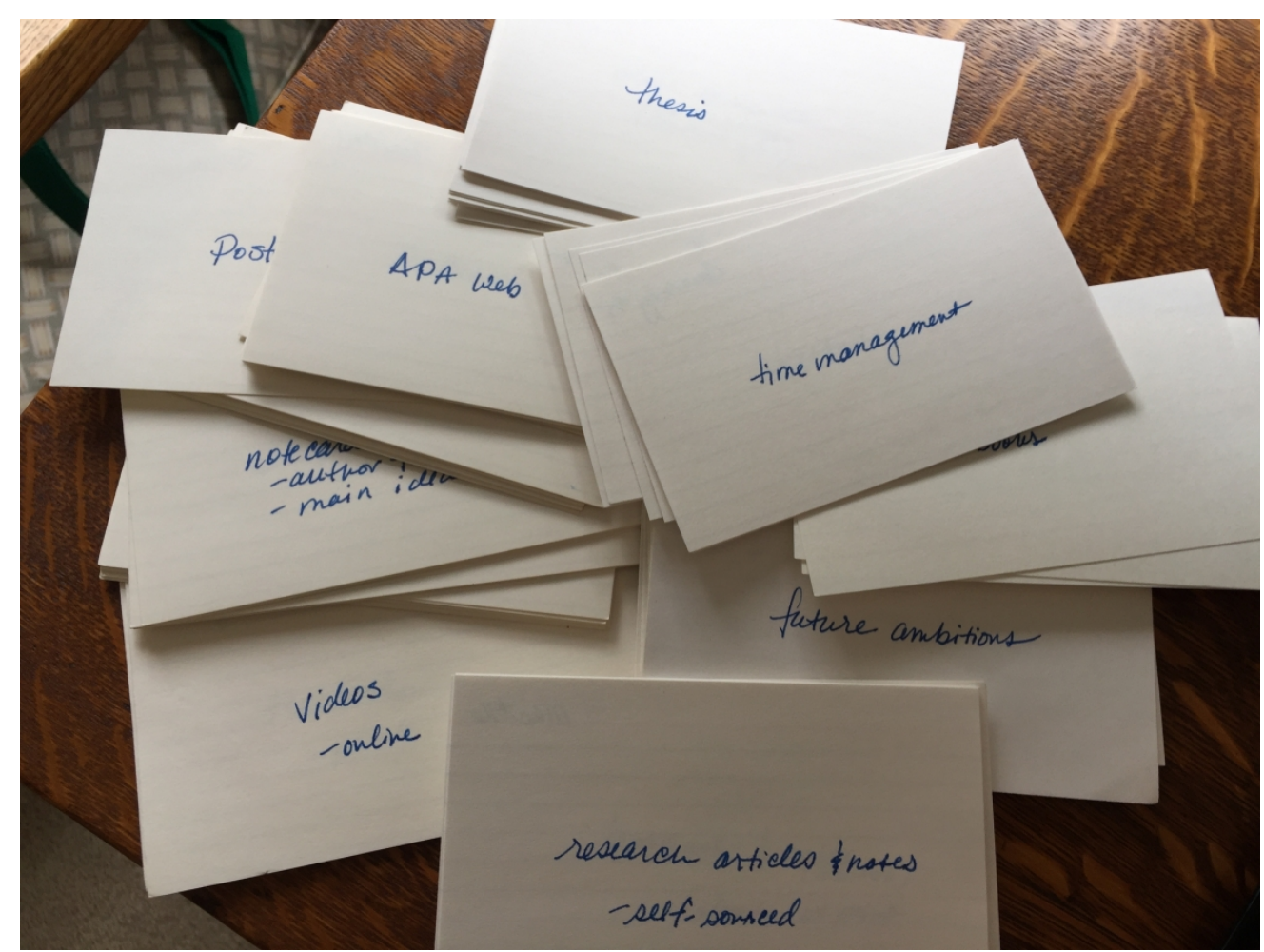

Cards labelled by student-researchers with 'that which informs' their masters' work $1151 \times 863 \mathrm{~mm}(72 \times 72$ DPI $)$ 
Table 1: Illustrative quotes \& codes assigned to initial categories

\begin{tabular}{|c|c|c|c|}
\hline & $\begin{array}{c}\text { What student- } \\
\text { researchers perceive as } \\
\text { information }\end{array}$ & $\begin{array}{c}\text { How student-researchers } \\
\text { determine what } \\
\text { information requires } \\
\text { individual management }\end{array}$ & $\begin{array}{l}\text { What strategies student- } \\
\text { researchers develop for } \\
\text { achieving academic } \\
\text { information management }\end{array}$ \\
\hline Mac & "Something I can trust" & "Digesting...core knowledge" & "Make outlines of every article" \\
\hline Jack & “Hoops to jump" & "Means to an end" & "A very contained system" \\
\hline Katie & $\begin{array}{l}\text { "Class discussion \& } \\
\text { participation" }\end{array}$ & "I'm passionate about it" & "Theory to practice" \\
\hline Melony & "Personal experience" & "My own personal growth" & "Break it up into manageable chunks" \\
\hline Tori & "My professor" & "Having an impact" & "I'm a dedicate-the-day girl" \\
\hline Tom & "My database" & "It's the gold" & "Trial and error" \\
\hline
\end{tabular}




\section{Appendix I}

This table summarizes participant profiles using self-identified demographic detail and key points of observation about the 12 student-researchers in this study.

\section{Table 1: Participant profiles}

\begin{tabular}{|c|c|c|c|c|c|c|c|}
\hline No. & Pseudonym & Gender & Age & Field of study & $\begin{array}{l}\text { Thesis } \\
\text { status }\end{array}$ & Work status & Future plans \\
\hline 1 & Melony & Female & $18-24$ & $\begin{array}{l}\text { Education, } \\
\text { K-12 teaching }\end{array}$ & $\begin{array}{l}\text { In progress } \\
\text { (required) }\end{array}$ & $\begin{array}{l}\text { Part-time } \\
\text { (outside field) }\end{array}$ & $\begin{array}{l}\text { Practitioner career } \\
\text { path }\end{array}$ \\
\hline 3 & Tori & Female & $25-34$ & $\begin{array}{l}\text { Education, } \\
\text { K-12 teaching }\end{array}$ & $\begin{array}{l}\text { In progress } \\
\text { (required) }\end{array}$ & $\begin{array}{l}\text { Full-time } \\
\text { (in field) }\end{array}$ & $\begin{array}{l}\text { Long-term } \\
\text { academic goals }\end{array}$ \\
\hline 5 & Brenda & Female & $25-34$ & $\begin{array}{l}\text { Education, } \\
\text { K-12 teaching }\end{array}$ & $\begin{array}{l}\text { In progress } \\
\text { (required) }\end{array}$ & $\begin{array}{l}\text { Full-time } \\
\text { (in field) }\end{array}$ & Unsure \\
\hline 6 & Robin & Female & $18-24$ & $\begin{array}{l}\text { Education, } \\
\text { K-12 teaching }\end{array}$ & $\begin{array}{l}\text { In progress } \\
\text { (required) }\end{array}$ & $\begin{array}{l}\text { Full-time } \\
\text { (in field) }\end{array}$ & $\begin{array}{l}\text { Practitioner career } \\
\text { path }\end{array}$ \\
\hline 8 & Jack & Male & $25-34$ & $\begin{array}{l}\text { Education, } \\
\text { K-12 teaching }\end{array}$ & $\begin{array}{l}\text { In progress } \\
\text { (required) }\end{array}$ & $\begin{array}{l}\text { Full-time } \\
\text { (in field) }\end{array}$ & $\begin{array}{l}\text { Practitioner career } \\
\text { path }\end{array}$ \\
\hline 11 & Tom & Male & $25-34$ & $\begin{array}{l}\text { Business, public } \\
\text { admin. }\end{array}$ & $\begin{array}{l}\text { In progress } \\
\text { (optional) }\end{array}$ & $\begin{array}{l}\text { Full-time } \\
\text { (in field) }\end{array}$ & Unsure \\
\hline 12 & Katie & Female & $18-24$ & $\begin{array}{l}\text { Education, } \\
\text { counseling }\end{array}$ & $\begin{array}{l}\text { In progress } \\
\text { (optional) }\end{array}$ & $\begin{array}{l}\text { Full-time } \\
\text { (in field) }\end{array}$ & Unsure \\
\hline 14 & Julia & Female & $18-24$ & $\begin{array}{l}\text { Education, } \\
\text { K-12 teaching }\end{array}$ & $\begin{array}{l}\text { In progress } \\
\text { (required) }\end{array}$ & $\begin{array}{l}\text { Full-time } \\
\text { (in field) }\end{array}$ & $\begin{array}{l}\text { Practitioner career } \\
\text { path }\end{array}$ \\
\hline 15 & Courtney & Female & $25-34$ & $\begin{array}{l}\text { Education, } \\
\text { counseling }\end{array}$ & $\begin{array}{l}\text { In progress } \\
\text { (optional) }\end{array}$ & $\begin{array}{l}\text { Full-time } \\
\text { (in field) }\end{array}$ & Unsure \\
\hline 16 & Mac & Male & $18-24$ & $\begin{array}{l}\text { Psychology, } \\
\text { clinical }\end{array}$ & $\begin{array}{l}\text { In progress } \\
\text { (optional) }\end{array}$ & $\begin{array}{l}\text { Full-time } \\
\text { (in field) }\end{array}$ & $\begin{array}{l}\text { Doctoral goals, } \\
\text { clinical career path }\end{array}$ \\
\hline
\end{tabular}




\begin{tabular}{|l|l|l|l|l|l|l|l|}
\hline 17 & Mary & Female & $45-54$ & $\begin{array}{l}\text { Education, } \\
\text { counseling }\end{array}$ & $\begin{array}{l}\text { In progress } \\
\text { (optional) }\end{array}$ & $\begin{array}{l}\text { Full-time } \\
\text { (in field) }\end{array}$ & Unsure \\
\hline 18 & Butch & Male & $25-34$ & $\begin{array}{l}\text { Psychology, } \\
\text { clinical }\end{array}$ & $\begin{array}{l}\text { In progress } \\
\text { (optional) }\end{array}$ & $\begin{array}{l}\text { Full-time } \\
\text { (in field) }\end{array}$ & $\begin{array}{l}\text { Doctoral goals, } \\
\text { clinical career path }\end{array}$ \\
\hline
\end{tabular}


June 10,2020

Dear Dr. Huvila,

Many thanks to you and the reviewers for this chance to revise our article in response to your thoughtful and constructive comments. Please find all comments itemized on the left side of the table below, with responses referencing associated improvements on the right.

We very much appreciate your supportive peer review program, and we hope you agree this is a muchimproved article. We look forward to your decision. Thank you - The authors

\begin{tabular}{|c|c|}
\hline Reviewer comment & Changes made in response \\
\hline $\begin{array}{l}\text { R1: You should definitely look at "informed learning" } \\
\text { and how that fits in with information management } \\
\text { and information experience. You introduced the } \\
\text { concept but did not really talk about how it relates } \\
\text { with your results and what you're attempting to do } \\
\text { with the study. } \\
\text { The author/s introduced the concept of "informed } \\
\text { learning" but does not talk about it later in relation to } \\
\text { their findings. It is an interesting concept and it would } \\
\text { worthwhile for the authors to explore how that fits in } \\
\text { with their results. Otherwise introducing it does not } \\
\text { make any sense. } \\
\text { To reiterate, the "informed learning" angle might be } \\
\text { a good arena to look at. }\end{array}$ & $\begin{array}{l}\text { Clarification regarding the limited coverage of } \\
\text { informed learning has been added to the "Informed } \\
\text { Learning section (p. 8). }\end{array}$ \\
\hline $\begin{array}{l}\text { R2: I would recommend a few structural changes to } \\
\text { develop and improve this paper before publication: } \\
\text { 1. Streamline the methodology and reduce the } \\
\text { overall word count for this aspect of the paper, in } \\
\text { particular, seek out instances where you repeat } \\
\text { yourself and try to write in detail about (e.g.) the data } \\
\text { collection method, in one place. } \\
\text { 2. Consider adding more direct quotes and a little } \\
\text { more detail about the responses to the results } \\
\text { section } \\
\text { 3. Better link the discussion with the literature } \\
\text { presented in the review and think about your results } \\
\text { in the context of PIM } \\
\text { 4. Think about practical impact of the study and who } \\
\text { might benefit from this research. }\end{array}$ & $\begin{array}{l}\text { Structural changes have been made as follows: } \\
\text { 1. Method section trimmed throughout (p. 8-13) } \\
\text { 2. Participants quotes added to results section (p. } \\
15 \text { \& 16). } \\
\text { 3. Clarification re: secondary literature review } \\
\text { added to Discussion (p. } 17 \text { ) } \\
\text { 4. Sentence added to Conclusion (p. 20). }\end{array}$ \\
\hline $\begin{array}{l}\text { R2: A good range of literature is presented, and it is } \\
\text { summarised and synthesised competently. There is } \\
\text { appropriate comment on the size and shape of the } \\
\text { literature reviewed which helps set the study in } \\
\text { context. I like that different perspectives including } \\
\text { PIM, IL and IKM have been presented. Key terms are } \\
\text { defined well. }\end{array}$ & Thank you, no change required. \\
\hline $\begin{array}{l}\text { I'm not convinced the word cloud p.7 brings much to } \\
\text { the paper as a whole. I would suggest that key terms }\end{array}$ & Word cloud has been removed and text shortened. \\
\hline
\end{tabular}


and differences in conception are instead presented as a table.

R2: A brief summary paragraph at the end of the literature review would be one suggested improvement.

R2: The methodology is detailed and is described using suitable reference to the literature. It is very long though in the context of the paper, and my suggestion for improvement is that the authors look to streamline the methodology, as there are instances where material is a little repetitive e.g. Page 8 the second paragraph starting "In this study, academic information management..." is repeated on page 11.

The discussion on the constructivist grounded theory approach is very interesting and clearly written. The card sorting exercise is similarly clearly explained.

A table with details of the participants (e.g. age, gender, discipline) would improve the methodology.

Summary paragraphs added to this section (p. $6 \& 8$ ).

Method section trimmed throughout (p. 8-13)

Thank you, no change required

R2: The results are framed by a suitable discussion of the data analysis process, although I didn't find the table p.14 very helpful in terms of understanding how codes had been developed.

The results section is quite brief, and it is implied, although not explicitly stated that this paper represents interim findings from the doctoral study. I think this should be stated at the beginning of the results section.

There are few quotes from participants, and I think that streamlining the methodology and then freeing up a bit of space to lengthen the results section would ultimately improve the paper.

The discussion is interesting, but focuses more on the justification of and discussion of the value of constructivist grounded theory than it does on the subject-based literature. I was hoping that the author would be able to contextualise their results in relation to the well-presented literature on PIM, PKM, IL and information experience in the review, but only information experience is covered and there are no references to support the argument presented.

R2: The author makes a good point about the value in exploring this topic using constructivist grounded theory, although this is not exactly ground-breaking, it is interesting to have a methodological focus for

Clarification added to abstract and introduction (p. 12)

Table of participant profiles added as a new Appendix I, with in-line mention on p. 14.

Explanation of in vivo codes added to this section, $p$. 14.

Method section trimmed throughout (p. 8-13). Participants quotes added to results section (p. 15 \& 16).

Clarification re: research status \& secondary literature review added to Discussion (p. 17)

Sentence added to the Conclusion (p. 20). 
the paper. I suspect that the implications for practice that the study has the potential to generate have not yet been fully thought through, although it would improve the paper if the author could introduce some ideas about how the research might have practical impact on some potential audiences e.g. research supervisors, librarians who support research students. 